\title{
Reduplication as a Tool for Morphological and Phonological Analysis in Awetí
}

\author{
Sebastian Drude
}

Verbal reduplication in Awetí is always full reduplication of the stem, quite independently from its CV structure. There are no different formal reduplication types, but there is some variation in the semantic effects according to the verb class (transitive, active intransitive, stative). The reduplicated active verbs with consonant-final stems show an additional unstressed $-e$, which also occurs in some simple verbs and in certain forms of stative verbs. Reduplication provides evidence that this $-e$ and a related $-z \tilde{a}$ are separate morphs, different from inflectional affixes and the stem. Reduplication also contributes to deciding several phonological questions; most importantly, the abstract morphemefinal archiphonemes /P, T, K/ are confirmed. Also, the analysis of inherently oral vowels different from neutral vowels, be it in complementary distribution, has been strengthened. Although reduplication is not always a clear criterion to distinguish derivation from inflection, it can reveal the 'underlying' form of derivational affixes.

This study describes reduplication in verb forms of Awetí, a Brazilian indigenous language spoken by a small group living in three villages in the region of the headwaters of the Xingu River in Mato Grosso, central Brazil. Awetí does not belong to but is the closest relative of the well-known Tupí-Guaraní subfamily, the largest well-established branch of the Tupí family. Mawé, Awetí and Tupí-Guaraní together constitute a major branch of Tupí, "Mawetí-Guaraní" (Rodrigues and Dietrich 1997; Drude 2006; Drude and Meira, forthcoming).

The study of reduplication can contribute to the understanding of phonological and morphological units and processes. This is shown by discussing reduplication in connection with key issues in Awetí: nasalization, abstract morpheme-final phonemes, and the identification of the stem and of morpheme boundaries. To a lesser degree, reduplication can also be used for the identification of derivation vs. inflection. 
Sections 2 and 3 serve as a basis for the paper. Section 2 summarizes the phonological system of Awetí. Section 3 gives some basic morphological properties and presents some diagnostic affixes used in the remaining sections. Then section 4 gives a short general overview of verbal reduplication in Awetí. Section 5 describes the basic patterns of reduplication found with active (transitive and intransitive) verbs. The members of a small particular subclass of these active verbs end in an unstressed syllable; these are treated in section 6. Section 7 uses evidence from reduplication for a closer look at certain (morpho-)phonological alternations at the beginning and end of verbal stems. Reduplication with stative verbs is treated in section 8. Finally, section 9 discusses the domain of reduplication if derivational affixes occur. The most important findings are summarized in the conclusion in section 10.

\section{2 Phonemes and Phonotactics of Awetí}

Awetí has six oral vowels /i, $\dot{i}, u, e, a, o /$ and their nasal counterparts $/ \tilde{h}, \tilde{t}, \tilde{u}, \tilde{e}$, $\tilde{a}, \tilde{o} /$. In most non-final syllables one of six additional 'neutral' phonemes $/ \dot{i}, \underline{i}$, $\underline{u}, \underline{e}, \underline{a}, \underline{o}$ / occurs, marked by (non-IPA) underlining. These are phonologically unspecified for orality or nasality and acquire these features phonetically due to nasal harmony.

Besides the basic consonantal phonemes $/ p, t, k, k^{w}, ?, m, n, \eta, j, w, t s, z, h, l, r /{ }_{1}^{1}$ a small group of more abstract underspecified phonemes is postulated due to neutralizations. In particular, the contrast between the simple stops and their nasal counterparts $(p: m, t: n, k: \eta)$ is neutralized in the coda, giving rise to the archiphonemes $/ P, T, K /$, which harmonize with the nasality or orality of the preceding vowel (see section 7 ). The abstract (underspecified) archiphoneme $/ P /$, for instance, contains only the property "bilabial." Depending on the environment, it is realized after oral vowels as an unreleased $\left[p^{7}\right]$ (before pause or stops) or as a 'lenited' $[\beta]$ (before vowels- $/ \mathrm{T} /$ and $/ \mathrm{K} /$ are lenited to to $[r]$ and $[\gamma]$, respectively), and as $[m]$ after nasal vowels or before nasal consonants.

At the beginning of certain (in particular, modal and nominalizing) suffixes, there is an abstract consonantal phoneme $/ \% .^{2}$ After $[m, n, \eta]$ (that is, after $/ P, T$,

1 The status of $/ k^{w}, h /$ as basic consonantal phonological units is debatable. The phonetic realization is made explicit in all examples.

2 As is common for more abstract phonemes, there is no IPA symbol for this segment. We use a small raised circle. The segment contains only the properties 'oral' and 'stop/plosive.' 
$K /$ following nasal vowels), it is realized phonetically as a homorganic stop [ $p$, $t, k]$ and analogically as $[t]$ after $[j]$ or as $[p]$ after $[w]$. If / / occurs after $[p, t, k]$ (that is, after $/ P, T, K /$ following oral vowels), it inhibits their lenition, following

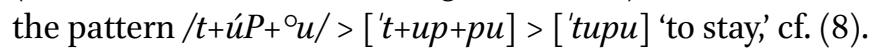

The abstract patterns in A shows the main positions for the basic disyllabic as well as for monosyllabic and trisyllabic stems, where brackets indicate that consonants are optional in all slots. The patterns $\mathrm{B}$ to $\mathrm{H}$ below refer to these abstract patterns.

$$
\text { A. }\left[\mathrm{C}_{1}\right] \mathrm{V}_{1}\left[\mathrm{C}_{2}\right] \mathrm{V}_{2}\left[\mathrm{C}_{3}\right]-\left[\mathrm{C}_{1}\right] \mathrm{V}_{2}\left[\mathrm{C}_{3}\right]-\left[\mathrm{C}_{1}\right] \mathrm{V}_{1}\left[\mathrm{C}_{2}\right] \mathrm{V}_{1}\left[\mathrm{C}_{2}\right] \mathrm{V}_{2}\left[\mathrm{C}_{3}\right]
$$

The phonemes distribute differently over these positions; for instance $/ \underline{i}, \underline{\dot{i}}, \underline{u}, \underline{e}$, $\underline{a}, \underline{o}$ / occur only in $\mathrm{V}_{1}$, and in $\mathrm{C}_{3}$ only /j, $w, P, T, K /$ occur; the latter three occur only here. The picture can be complicated, if rarely, by occurrence of glides between positions of the patterns A.

Awetí words are usually stressed on the last syllable of the stem (Drude 2011b). There are, however, a few paroxytonic stems with an additional final unstressed syllable (see section 6). Only a few suffixes, mostly derivational ones, attract lexical stress. In the phonological representations in this study, stress is marked by an acute accent over the vowel of the stressed syllable.

\section{3}

\section{Relevant Morphological Facts and Terms}

As far as verb forms are concerned, Awetí is a moderately agglutinating language. Typical verb forms of simple verbs contain three or four, those of derived verbs maximally seven morphs. For the ease of the reader, the morphs of verb forms in the text are separated by a middle dot '? (e.g., 'toK·tóK.e.tu'). Generally, only one derivational affix is present in any given verb form. The principal morphological positions or 'slots' of an Awetí verb form are as follows:

person voice causative STEM derivative aspect mood Awetí verb forms contain at most one person prefix referring either to the subject or to the object. ${ }^{3}$ The voice prefixes include te- 'reflexive' and to- 'reciprocal';

3 If not explicitly indicated otherwise, all person prefixes in transitive verbs in the examples refer to the subject. 
the same slot may be occupied by incorporated nouns instead. Before an active intransitive stem, a derivational prefix may occur. With other stems, derivational affixes immediately follow it (cf. section 9). Many verb forms take one of the two aspect suffixes -ju or -zoko (see Tables 3 and 4 below). The perfective forms are unmarked. Finally, many moods, most of them used for subordination, are marked by a suffix occurring at the very end of the main verb. One of these, $-t u$ (see Table 1 below), is frequently used in this paper. Also the negative suffix $-(\dot{t}) k a$ appears in the final slot.

By the notion 'stem' (of a word) I here understand a morph or sequence of morphs which carries the lexical meaning of the word and which serves as a basis for adding one or several inflectional affixes (yielding complete inflected forms of the word), and/or as a basis for derivation or composition. The result of these latter is again a stem: the stem of a complex word. I maintain the traditional distinction between derivation (yielding new stems with a different lexical meaning) and inflection (marking functional categories of different forms of the same lexical word), although there may be cases which are difficult to assign.

For the purposes of this paper, I focus on certain inflected forms of verbs which have, in particular, certain affixes that are useful for identifying morpheme boundaries. These forms are: the absolute form (Tables 1 and 2) which is the citation form used to refer to the verb itself; the imperfective forms (Table 3), meaning: 'to do ... as a habit,' or 'to be about to do ...'; and the progressive forms (Table 4), general meaning: 'to be doing ...,' with stative verbs possibly also 'to become ....'

TABLE 1 Suffixes and their allomorphs in

absolute verb forms: $-t u /{ }^{\circ} u$ 'ABs,' $-z \tilde{a} /-\tilde{a}^{4}$

Stem ends in: Vowel Consonant

Verb type:

Active $\quad-t u \quad-{ }^{\circ} u$

Stative $\quad-z \tilde{a} \cdot t u \quad-\tilde{a} \cdot t u$

4 The element $-z \tilde{a} /-\tilde{a}$, with empty lexical/functional semantics, is glossed zẽ. See below section 6. 
TABLE 2 Prefixes and their allomorphs in absolute verb forms:

$t$ - $A B S,{ }^{5} n-/ n \tilde{a}^{-6}$

Stem begins with: $\quad$ Vowel Consonant

Verb type:

Transitive active $\quad n-\quad n \tilde{a}-$

Intransitive active \& stative $\quad t^{-} \quad-^{7}$

TABLE 3 Allomorphs of the imperfective suffix -zoko/-oko/-e.zoko 'IPFV'

Stem ends in: $\quad$ Vowel $\quad / T / 8 \quad$ Other consonants

Verb type:

Active $\quad-z \underline{0}$ ko $\quad-z o k o \quad-o k o$

Stative $\quad-z \underline{0}$ ko $\quad$-ẹ.zoko $\quad$-ézoko

TABLE 4 Allomorphs of the progressive suffix -ju/- ${ }^{\circ}$ eju/-e.ju 'PROG'

\section{Stem ends in: Vowel $\quad|T, j| \quad$ Other consonants}

Verb type:

$\begin{array}{llll}\text { Active } & -j u & -j u & -{ }^{\circ} \text { eju } \\ \text { Stative } & -j u & -\underline{e} \cdot j u & -\underline{e} \cdot j u\end{array}$

5 The elements $t$ - and $-t u /{ }^{\circ} u$ in intransitive verbs can be seen as parts of a circumfix 'ABs.'

6 In absolute forms, this 3rd person object prefix could also be glossed as 'ABs' and/or be analyzed as part of a circumfix. Note that Awetí women use $t$ - or $\underline{i}$ - instead. See Drude (2002).

7 There is no prefix in absolute forms of consonant-initial intransitive verbs, but a stem-initial $/ p /$ changes to $/ \mathrm{m} /$.

8 After oral vowels, $/ T /$ is phonetically deleted before -zoko. After nasal vowels, $/ T /$ surfaces as $[n]$ which apparently behaves as any other consonant: the suffix seems to be just -oko. However, phonologically we postulate /...T-z.../ in both cases. The apparent idiosyncrasies arise on the phonetic level by the rules of solving sequences of homorganic consonants: $\left[\ldots t z_{\imath} \ldots\right]>\left[\ldots z_{\imath} \ldots\right] ;$ but $\left[\ldots n z_{\imath} \ldots\right]>[\ldots n \ldots]$. 
Henceforth we refer to the suffixes above as $-t u,-z o k o$ and $-j u$, respectively. In the text, verbs are cited by their absolute form, with the affixes in Tables 1 and 2.

For the finite forms, the examples show mostly third person forms. The third person prefixes, glossed ' 3 ', are $\underline{o}$ - (resyllabified as $[w]$ before certain vowels) for active intransitive verbs, $w e j$ - for transitive verbs, and for stative verbs $\underline{i}-$ (before consonants) or $t$ - (before vowels). The patterns of reduplication are the same with other person categories. Note that singular and plural are not distinguished in third person Awetí verb forms. In the free translations, we usually use 'he' or 'him' ('it' for inanimate entities), but in fact all third person pronouns could be used: 'he/she/it/they' or 'him/her/it/them.'

All forms presented here are unmarked for tense, that is, they belong to the non-future category. In the free translations, in particular of perfective forms (forms unmarked for aspect), we usually choose past tense because this reflects the perfective meaning and is the unmarked translation given by Awetí speakers.

In Awetí, reduplication as a productive regular morphological process occurs only with verbs. ${ }^{9}$ Generally, the input for reduplication is a verb stem, not including inflectional affixes. ${ }^{10}$ In many cases, the input may consist of a stem formed by derivation (that is, the derivational affix, such as a valence changing affix, is reduplicated together with the original simple stem), but this does not work with all affixes or with all stems (see section 10).

Reduplication has been assumed to be suffixing or 'postfixing' in the analysis for all Tupian languages we are aware of (Jensen 1998; Rodrigues 1953; Seki 200o). But, in fact, as reduplication in Awetí is always full reduplication, it is almost impossible to decide which of the two tokens would be the 'base' and which the 'reduplicant.' If only some but not all morphs of a stem are copied, these are often the first morphs, which could be taken as evidence for prefixing reduplication in Awetí. Generally, we sympathize with 'projectionlinearization' approaches to reduplication which do not distinguish between a

$9 \quad$ Reduplicated forms of postpositions and idiophones are not discussed in this paper.

10 In contrast, Rose (2007; 2005) observes that in Tupí-Guaraní languages (parts of) person prefixes can be included in the base and reduplicant in order to complete a two-syllabic reduplication pattern. 
base and a reduplicant (affix). ${ }^{11}$ Thus we speak generally rather of the 'left hand copy' and the 'right hand copy' of the 'input' (usually the stem of the original, non-reduplicated verb) instead of the 'reduplicant' and the 'base.'

The formal properties of reduplication in Awetí are summarized below. They are all extensively described and exemplified in the following sections. For quick orientation, some examples (only stems, not entire inflected word forms) are also given.

\subsection{Formal Properties of Reduplication in Awetí}

a. Stems with final stress are copied entirely, independently of their syllable structure (e.g. tó > to tó; ekó > éko ekó; motó > moto motó; see section 5);

b. Active verbs with stems ending in a consonant show a final additional unstressed -e in the reduplicated form (e.g. úT > uT úT-e; $m \underline{\underline{e} z u \tilde{u} K}>m \underline{\dot{z}} z \tilde{u} K \sim$

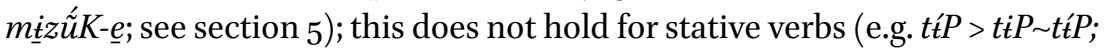
potíj > potitj pot t́j; see section 8);

c. Stems with a final unstressed syllable do not copy the final parts $-\underline{e}$ or $-\tilde{a}$ (after

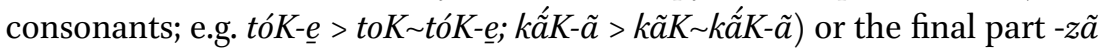

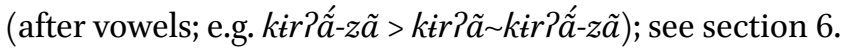

In the terms given in the previous section, although highly productive $\mathrm{e}^{12}$ and formally regular, reduplication in Awetí is clearly not an inflectional but a derivational (word-formation) process. In other words, reduplication is used to obtain new lexical items (verbs) with meanings which are systematically related to the meaning of the original simple verb (with the non-reduplicated stem).

Semantically, different effects of reduplication exist, but these are not correlated with formal distinctions. In particular, there is no semantic distinction between monosyllabic versus di- or multisyllabic reduplication. This is because there is only total/full, no partial reduplication in Awetí, independent of the number of syllables. There are, however, differences between lexical verb classes (transitive vs. active intransitive vs. stative verbs), which in turn reflect semantic differences (stative verbs mostly denote properties).

The main lexical-semantic effects of reduplication are those listed below, ordered (impressionistically) by importance or frequency. The most frequent effects are related to pluractionality. Often several of these effects occur in combination [e.g. (2)], or the meaning of the resulting verb varies [e.g. (1), (3)],

11 See, for instance, Raimy (2000), Halle (2008), Reiss \& Simpson (2009).

12 We have not found any example of a verb which would not permit reduplication. 
applying one or another semantic effect. At least one example each is indicated in the following list:

\subsection{Semantic Effects of Reduplication in Aweti}

a. The action/event happens repeatedly (several times, simultaneously or in sequence) (3) (15) (24);

b. There are several subjects of the action/event, simultaneously or not (in particular with intransitive verbs) (11) (15) (17);

c. With transitive verbs, the action/event happens with respect to several objects (5) (31). Sometimes there is an additional distributive meaning component $(5)$ (28). In the case of ditransitive verbs, plurality may concern the recipient/benefactive $(3)$;

d. With stative verbs (property concepts), the property does not hold fully (attenuation) but rather 'more or less' (26);

e. The action/event involves several different directions (mostly with verbs of motion) (2) (11) (22);

f. Several other somewhat less frequent meaning components are partly lexicalized: lack of control (2) (10); - 'little-by-little' (after 18) (35);-inchoative ('is beginning to ...') (2) (35);- -lack of reason or purpose (6).

We now turn to describe and illustrate reduplication in more detail, starting with active verbs.

\section{5 \\ Reduplication with Active Verbs: Basic Patterns}

As there is no Awetí verb with a stem consisting of only one phoneme. One of the simplest patterns for verb stems is $\mathrm{C}_{1} \mathrm{~V}_{2} \cdot{ }^{13}$ As for all cases of reduplication with vowel-final stems with stress on the last syllable, the reduplicated verb has just two complete copies of the input, the original stem. Thus, pattern $\mathrm{B}$ holds for a $\mathrm{C}_{1} \mathrm{~V}_{2}$ stem.

B. $\mathrm{C}_{1} \mathrm{~V}_{2}>\mathrm{C}_{1} \mathrm{~V}_{2} \sim \mathrm{C}_{1} \mathrm{~V}_{2}$

Consider for instance the verb tó tu ${ }^{14}$ 'to go, to leave' (stem: tó) and its reduplicated counterpart to·tótu which has two meanings: 'to flee' (many, typically

13 The indices refer to the patterns $A$ in section 2. For the pattern $V_{2} C_{3}$, see (8), below.

14 For the absolute forms of verbs used as citation forms see section 3. 
in different directions) and 'to wander' (as a small child). We show the simple (third person) perfective form in (1a,c) and the absolute citation form in $(\mathrm{lb}, \mathrm{d})$ for both verbs. In all examples we show a phonetic representation in the first line and a phonological representation in the second line. ${ }^{15}$ The morphs are glossed in the third line, and free translations are given in the fourth and possibly a fifth line.
a. $\left[\jmath^{\prime} t 0\right]$
b. ['tstu]
c. $[$ oto'to $]$
/o-tó/
/tó-tu/
/o-to tó/

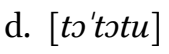 /to tó-tu/
3-go go-ABS
3-go go
go go-ABS
'He went'
'to go'
'They fled.'
'to flee (many)/
'(The child) wandered.'
to wander'

Similarly, pattern C holds for disyllabic stems with final stress and beginning and ending in a vowel. Again, the whole stem is copied without further modifications.

C. $\quad \mathrm{V}_{1} \mathrm{C}_{2} \mathrm{~V}_{2}>\mathrm{V}_{1} \mathrm{C}_{2} \mathrm{~V}_{2} \sim \mathrm{V}_{1} \mathrm{C}_{2} \mathrm{~V}_{2}$

Consider the verb t.ekó.tu 'to walk' and its reduplicated counterpart t.eko.êkó.tu with the meaning 'to begin to walk' (typically stumbling, trying again and again, as a toddler, also 'walking around without a clear direction'), exemplified in (2).

$(2)$
a. $w \varepsilon^{\prime} k s$
b. $w \varepsilon, k a \varepsilon^{\prime} k s$
o-ekó o-e eko ekó
3-walk 3-walk walk
'He walked.'
'(The child) began to walk (stumbling).'

Also consonant-initial and vowel-final disyllabic stems with final stress are completely reduplicated, see pattern $\mathrm{D}$.

D. $\mathrm{C}_{1} \mathrm{~V}_{1} \mathrm{C}_{2} \mathrm{~V}_{2}>\mathrm{C}_{1} \mathrm{~V}_{1} \mathrm{C}_{2} \mathrm{~V}_{2} \sim \mathrm{C}_{1} \mathrm{~V}_{1} \mathrm{C}_{2} \mathrm{~V}_{2}$

15 The phonological representation indicates morpheme boundaries by hyphens or, between the two copies in reduplicated forms, the tilde ' $\sim$ '. In (1), we indicate the phonetic/phonological status by brackets and slashes, respectively. We will not do so in the rest of this study. Awetí forms in italics in the main text are always phonological if not marked by brackets. 
For instance, consider the transitive verb nã.motó.tu 'to give' and its reduplicated counterpart nã.moto.motó.tu meaning 'to give repeatedly' or 'to give to several people, to distribute.' We only show the finite forms for these words in (3), adding a further verb derived from the reduplicated verb nã.moto.motó.tu by means of the completive suffix -wã.

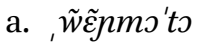

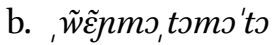
wej-motó
wej-moto motó
3-give
3-give give
c. , $\tilde{w} \tilde{\varepsilon} n m s$, tomsto'wã
wej-moto - moto-wá
'He gave it.'
'He gave repeatedly.' 3-give give-COMPL
'He gave to 'He gave it all, repeatedly' several people.'
'He gave it all to several people'

In the case of transitive verbs the stem of which starts with a vowel, forms with subject-agreement exhibit an additional / $t$ / between the person prefix and the stem proper. In principle, three analyses are possible for this $/ t /:$ (a) it is part of the stem (that is, the stem has an allomorph with an additional segment $/ t$ / which occurs after subject person prefixes); (b) it is part of the prefix (that is, the subject prefixes have allomorphs with a final segment $/ t$ / occurring immediately before vowel-initial stems); (c) it is a morph by itself, for instance a generic object marker. ${ }^{16}$ The three possibilities are illustrated in (4), together with an object-centered form of the same verb $n \cdot a+\hat{t}^{\prime} \cdot t u$ 'to tie.'
a. $w \tilde{\varepsilon} n t a \tilde{I}^{\prime} n t \tilde{\imath}$ wej-tatî́
wejt-atî́ wej-t-a $\underline{t} \hat{\imath}$
b. kãnã'ntĩ
3.subJ-tie 3.subJ-tie 3.suBJ-OBJ?-tie
$k \underline{a} j$ - $\underline{a} t \hat{\imath}$
'He tied it.'
1.INCL.OBJ-tie
'[Someone] tied you and
me.'

An argument against hypothesis (a) is provided by reduplication data: the /t/ is not reduplicated, which suggests that it is not part of the stem. See the

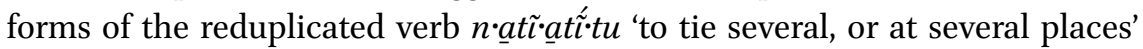
in $(5) \cdot{ }^{17}$

16 It is quite possible that the $/ t$ / is at least historically related to the third person prefix of stative verbs (and of nouns, in the female variety of Awetí, cf. Drude 2002).

17 The morpheme breaks in (5a) follow analysis (b). Still, the other options are not completely refuted, not even (a); see footnote 28 . 


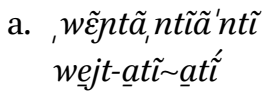
b. ,kãnã $n t i \tilde{a} \tilde{a}^{\prime} t_{t}$
$k \underline{a j}$-ạtĩ $\underline{a} t \hat{\imath}$
3.subJ-tie tie
1.INCL.OBJ-tie tie
'He tied them all.'
'[Someone] tied everyone of us (including you).'
'He tied it all over.' '[Someone] tied us at many places.'

The pattern of reduplication identified so far, see patterns B, C and D, changes slightly when the simple stem ends in a consonant. Also in this case the entire original simple stem is copied, but in addition there is now a final unstressed $-\underline{e}$ in the reduplicated form, as illustrated by the simple finite forms

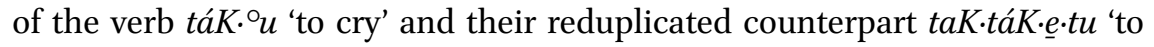
cry often (for no reason)' in (6). They exemplify the pattern E, below, for a consonant-initial monosyllabic stem. Importantly, the - $\underline{e}$ does not show up between the two copies of the stem, where it would phonotactically make sense (avoiding consonant encounters, as happens generally in Awetí morphology). So this $\underline{-e}$ is evidently not a phonetic or phonological phenomenon.

E. $\quad \mathrm{C}_{1} \mathrm{~V}_{2} \mathrm{C}_{3}>\mathrm{C}_{1} \mathrm{~V}_{2} \mathrm{C}_{3} \sim \mathrm{C}_{1} \mathrm{~V}_{2} \mathrm{C}_{3}-\underline{e}$

$$
\begin{aligned}
& \text { a. } \left.\jmath^{\prime} t a \vec{k} \quad \text { b. }\right\lrcorner \text { taḱtaye } \\
& \text { o-táK } \quad \underline{o} \text {-taK táK-e } \\
& \text { 3-cry } \quad 3 \text {-cry } \sim \text { cry-TV } \\
& \text { 'He cried.' 'He cried often (for no reason).' }
\end{aligned}
$$

We gloss this final $\underline{\underline{e}}$ as 'thematic vowel' ("TV"). ${ }^{18}$ It does not seem to have a proper meaning, neither lexical nor functional, being comparable to thematic vowels or composition junctures in other languages. Still, it seems to have morphological status, being part of the stem derived by reduplication. Note, for instance, that the $-\underline{e}$ is not omitted before inflectional suffixes, which appear in their post-vowel allomorph. Consider for example the imperfective forms with the suffix -zoko (compare Table 3 , above), given in (7). ${ }^{19}$

\footnotetext{
18 Despite the label, we assume thematic vowels to be morphs, similar to 'epenthetic interfixes' in composition (cf. the German Fugenmorphem, or the French e muet).

19 Note that the second possible semantic interpretation of the imperfective, 'to be about to ..., is not possible, or much less common, with reduplicated verbs.
} 

a. o'tajoks
o-táK-oko
b. stak'tayezzoks
3-cry-IPFV
o-taK táK-e -zoko
'He used to cry.'
3-cry cry-TV-IPFV
'He is about to cry.'
'He used to cry frequently (for no reason).'

Also before the mood suffixes, the morph $-\underline{e}$ is obligatory in the reduplicated verbs. This is illustrated by the two citation forms given in (8). Again, the absolute suffix $-t u /{ }^{\circ} u$ appears in its post-vowel allomorph $-t u$ in the reduplicated verb.
a. 'taku
b. $t a k^{\prime}$ 'tajetu
táK- ${ }^{\circ} u \quad$ taK $\sim$ táK-e-tu
cry-ABs cry cry-TV-ABs
'to cry' 'to cry repeatedly (for no reason)'

The thematic vowel $\underline{e}$ is different from the $/{ }^{\circ} \underline{e} /$ which occurs at the beginning of the allomorph $-{ }^{\circ}$ eju of the aspect suffix -ju, see Table 4. The latter contains the initial abstract consonant $/ \%$ which inhibits lenition of final stops and attracts word accent. Both are illustrated in (9a), in contrast to $(9 b)^{20}$ [and also to (6b), (7b) and (8b)].
(9)
a. sta'kcju
o-taK- ${ }^{\circ}$ ju
b. stak'tayeju
3-cry-PROG
o-taK táK-e-ju
3-cry cry-TV-PROG
'He was crying.' 'He was crying repeatedly (for no reason).'

On the other hand, the $/{ }^{\circ} \underline{e} /$ in $-{ }^{\circ}$ eju does not occur with a stem ending in $/ T /$, where the progressive suffix appears in its shorter form -ju, phonetically fusing with the stem (by regular deletion of the first segment of a sequence of two homorganic consonants). Compare the perfective and progressive forms of the

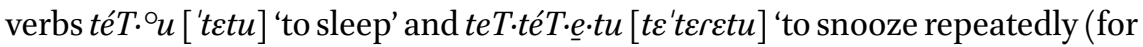
instances),' in (1ob and d).
(10) a. s'tet
o-téT
3-sleep
'He slept.'

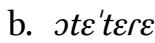
o-teT téT-e 3-sleep sleep-TV
'He snoozed repeatedly.' 


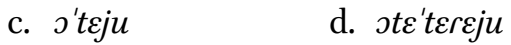

$$
\begin{aligned}
& \text { o-téT-ju o-teT téT-e-ju } \\
& \text { 3-sleep-PROG 3-sleep sleep-TV-PROG } \\
& \text { 'He was sleeping.' 'He was snoozing repeatedly.' }
\end{aligned}
$$

The pattern for vowel-initial stems also shows the thematic vowel. In the case of a monosyllabic consonant-final stem with pattern $\mathrm{V}_{2} \mathrm{C}_{3}$, the pattern $\mathrm{F}$ holds.

$$
\text { F. } \quad \mathrm{V}_{2} \mathrm{C}_{3}>\mathrm{V}_{2} \mathrm{C}_{3} \sim \mathrm{V}_{2} \mathrm{C}_{3} \underline{\underline{e}}
$$

This pattern is illustrated below with forms of the verb $t \cdot u$ T $T{ }^{\circ} u$ 'to come' and t.uT.úT.e.tu 'to gather' (that is, for several to come, from different directions): in (11) with perfective forms, in (12) with imperfective forms, and in (13) for the absolute forms. [Here, $\mathrm{V}_{2}=u$ and $\mathrm{C}_{3}=T$, compare patterns $\mathrm{A}$ above.]
a. s'ut
b. su'rure
$o-u ́ T$
$\underline{o}-u T \sim u ́ T-\underline{e}$
3-come
3-come come-TV
'He came.'
'They gathered.'

(12)
a. o'uzəos
o-úT-zoko
b. эu'rurezəok
3-come-IPFV
o-uT úT-e-zoko
'He used to come.'
3-come come-TV-IPFV
'He is about to come.'
(13) a. 'tutu
$t-u ́ T-{ }^{\circ} u$
ABS-come-ABS
'to come'
b. tu'ruretu
$t-u T \sim u ́ T-\underline{e}-t u$
ABS-come come-TV-ABS
'to gather'

Further patterns could be added, such as the patterns $G$ or still others for stems with three or more syllables. Two of them will occasionally be illustrated below, see the corresponding examples.
G.
a. $\mathrm{C}_{1} \mathrm{~V}_{1} \mathrm{C}_{2} \mathrm{~V}_{2} \mathrm{C}_{3}$
$>\mathrm{C}_{1} \mathrm{~V}_{1} \mathrm{C}_{2} \mathrm{~V}_{2} \mathrm{C}_{3} \sim \mathrm{C}_{1} \mathrm{~V}_{1} \mathrm{C}_{2} \mathrm{~V}_{2} \mathrm{C}_{3}-\underline{e}$
b. $\mathrm{C}_{1} \mathrm{~V}_{1} \mathrm{~V}_{2} \mathrm{C}_{3}$
$>\mathrm{C}_{1} \mathrm{~V}_{1} \mathrm{~V}_{2} \mathrm{C}_{3} \sim \mathrm{C}_{1} \mathrm{~V}_{1} \mathrm{~V}_{2} \mathrm{C}_{3}-\underline{e}$
c. $\mathrm{V}_{1} \mathrm{C}_{2} \mathrm{~V}_{2} \mathrm{C}_{3}$
$>\mathrm{V}_{1} \mathrm{C}_{2} \mathrm{~V}_{2} \mathrm{C}_{3} \sim \mathrm{V}_{1} \mathrm{C}_{2} \mathrm{~V}_{2} \mathrm{C}_{3}-\underline{e}$ 
Interestingly, there is a small group of simple (not reduplicated) verbs which also have the thematic vowel $-\underline{e}$, or an unstressed final element $-(z) \tilde{a}$. These are discussed in the next section.

With a small group of non-reduplicated paroxytonic verbs it is not immediately clear whether the final $-\underline{e}$ or $-(z) \tilde{a}$ is a part of the stem or not. Consider the verb ['toyetu] 'to tear' (unidimensional objects such as threads, lines, ropes, etc.). Two characteristic forms and my analysis are given in (14).

$$
\begin{aligned}
& \text { a. o'toye b. o'toyeju } \\
& \text { o-tóK-e } \quad \underline{e} \text {-tóK-e-ju } \\
& \text { 3-tear-TV 3-tear-TV-PROG } \\
& \text { 'It tore.' ' It was tearing.' }
\end{aligned}
$$

Words like ['toyetu] are phonologically suspicious. Generally all Awetí words have lexical stress on the last syllable of the stem; exceptions involve known morphological processes. Also, the phonetic segment $[\gamma]$ generally occurs as an allophone of $/ K /$, which only occurs morpheme-finally. So is the phonological form tóye-tu or tóK-e-tu? Without the data from reduplication, we would not have a compelling reason for assuming a morphological boundary before the final $/ \underline{e} /$, because there is no form of the verb ['toyetu] without this /e/.

In the reduplicated counterpart [tok'toyetu] 'to tear (many unidimensional objects, and/or several times, at several places),' the suspicious /e/ is not included in the left hand copy, see $(15 \mathrm{a})$. The $[\gamma]$ in the right hand copy corresponds to $[\hat{k}]$ in the left hand copy, pointing indeed at an underlying phoneme $/ K /$ (cf. section 2).
a. $ว t \jmath \hat{k}^{\prime} t \partial y \varepsilon$
o-toK tóK-
b. 'tojetu
3-tear tear-TV
tóK-e-tu
'(The rope) tore at several places.'
tear-TV-ABs
'They (e.g., many ropes) tore.'
'to tear (unidimensional)'

We conclude that the $/ \underline{e} /$ is not part of the input of the reduplication process (nor of the 'base,' in terms of reduplication as affixation); the part of the original verb to be reduplicated consists of only the 'proper' stem. Therefore, we can assume a morphological border before the /e/ not only in the complex word 
toK·tóK.e.tu but also in the simple verb tóK.e.tu. This indicates that the final -e is, again, a thematic vowel, already in the non-reduplicated word, see (14) and $(15 \mathrm{~b}) .{ }^{21}$ Thus, the pattern $\mathrm{H}$ holds for reduplication in this case and in similar cases.

H. $\quad \mathrm{C}_{1} \mathrm{~V}_{2} \mathrm{C}_{3} \underline{\underline{e}} \underset{ }{\underline{e}} \mathrm{C}_{1} \mathrm{~V}_{2} \mathrm{C}_{3} \sim \mathrm{C}_{1} \mathrm{~V}_{2} \mathrm{C}_{3} \underline{\underline{e}}$

Although the thematic vowel $-\underline{e}$ seems to be more common with monosyllabic stems, the regular pattern $\mathrm{H}$ holds analogously with more syllables. For example toróK.e.tu 'to tear' (of bidimensional objects, that is, of cloth, nets, paper, etc.) has its reduplicated counterpart toroK·toróK.e.tu 'to tear (many bidimensional objects, and/or several times, at several places).'

There is a second even smaller class of active verbs that have another final unstressed vowel, namely an /ã / (intrinsically nasal) with similar properties as the /e/ discussed above. For phonological reasons a morphological boundary before that $-\tilde{a}$ is even more obvious than in the case of the thematic vowel -e: the nasality of the $-\tilde{a}$ usually does not spread to the proper stem, as would be expected if it were the last vowel of the stem. ${ }^{22}$ Also, as I will show below, there is a variant of - $\tilde{a}$ after vowels, $-z \tilde{a}$, where the $/ z /$ (a segment that cannot occur in position $\left.\mathrm{C}_{3}\right)$ is also not included in the reduplication. This is the same $-(z) \tilde{a}$ of Table 1, above.

Consider first the example of the intransitive verb kấK.ã.tu [k'ãyanntu] 'to dry' in (16) and its reduplicated counterpart kã K·ká́K·ã.tu [kãyk'ãyãntu] '(for several) to dry' in (17). ${ }^{23}$ The morph - $(z) \tilde{a}$ does not have a clearly identifiable meaning although formerly it might have been a derivational suffix that derived verbs from nouns (however, the relation of kấK. ã.tu 'to dry' to the noun kấK $[k a \tilde{\eta}]$ 'bone' is hard to establish). For lack of a clear semantic/functional label, this morph is here glossed just as 'ZÃ.'

21 In other words, the complete stem of all forms of tóK.e.tu consists of two morphs, the 'proper' stem tó $K$ and the thematic vowel -e, similar to many inflected verb forms in Romance languages.

22 Admittedly, this could be accounted for by postulating nasalization rules which refer to lexical stress, as they are known in Tupí-Guaraní languages with nasal harmony. In many cases, the stem is also nasal, which can be explained by lexicalization, where the morphological boundary tends to disappear.

23 The stem $k \tilde{a} K$ of this verb is intrinsically nasal. In section 8 on stative verbs there will be examples that illustrate that the nasality of the morph $z \tilde{a}$ does not spread to an oral stem. 
(16)
a. $\tilde{s}^{\prime} \eta k \tilde{a} \eta \tilde{a}$
$\underline{o}-k \tilde{a} K-\tilde{a}$
b. $\tilde{s}^{\prime} \eta k \tilde{\eta} \eta \tilde{a} \eta \tilde{u}$
3-dry-zÃ
$\underline{o}-k \tilde{a} K-\tilde{a}-j u$
'It dried.'
3-dry-zÃ-PROG
'It was drying.'
a. $\tilde{\eta} k \tilde{a} \eta^{\prime} k \tilde{a} \eta \tilde{a}$
b. kãy'kãyãntu
$o-k a \tilde{K} \sim k \tilde{a} K-\tilde{a}$
$k \tilde{a} K \sim k \tilde{a} K-\tilde{a}-t u$
3-dry dry-zÃ
dry dry-zÃ-ABs
'Several dried.'
'(for several) to dry'

For a vowel-final stem with an additional morph $-(z) \tilde{a}$, see the example with the monosyllabic stem $p \tilde{o}$ 'to be loaded, filled up (as of a canoe)' and its reduplicated counterpart põ.põ meaning '(for many) to be loaded, filled up' in (18). ${ }^{24}$ Despite their semantics, these are active verbs.
(18)
a. $\tilde{\jmath}^{\prime} m p \tilde{\partial} z \tilde{a}$
o-pó́-zã
b. $\tilde{\jmath} m p \tilde{\jmath} ' m p \tilde{z} z \tilde{a}$
3-be.full-zÃ
$\underline{o}-p \tilde{o} \sim p \tilde{o}-z \tilde{a}$
'It was full.' 3-be.full be.full-zÃ
'Several (e.g., boats) were filled up.'

A disyllabic example is kirrá̃.zã.tu 'to gain weight/be fat' and the reduplicated kir?ã.kir?á́.zã.tu 'to (begin to) gain weight (little by little)' (as after a serious illness). Again, as the previous example, this is an active verb whose semantics are like that of a stative verb, denoting a property. (This may be related to the occurrence of $-(z) \tilde{a}$.) There is also a disyllabic consonant-final example, ?atú $K \cdot \tilde{a} \cdot t u$ 'to burn down' and PatũK·?atú $K \cdot \tilde{a} \cdot t u$ '(for several) to burn down.'

In sum, verbs with the final unstressed morph $-(z) \tilde{a}$ reduplicate only the proper stem, without $-(z) \tilde{a}$, as formulated in pattern I.

\section{I. $\quad \operatorname{STEM}-(z) \tilde{a}>\operatorname{STEM} \sim \operatorname{STEM}-(z) \tilde{a}$}

24 The citation forms of these verbs, mố.zã $\cdot t u$ and mõ.mố.zã $\cdot t u$, will be explained in the following section. 


\section{$7 \quad$ Reduplication and the $/ \mathbf{p} /-/ \mathbf{m} /$ Allomorphy and Final Consonants}

Consider the verb $m \underline{i} z \tilde{u} K \cdot{ }^{\circ} u$ 'to stamp one's foot.' All inflected forms contain the stem $p \underline{\underline{i} z \tilde{u} K}$, an allomorph which begins with $/ p /$, as shown in (19a).

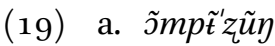
o-pizzũK
b. $m \tilde{t}^{\prime} z \tilde{u} \eta k u$
3-stamp.foot
$m \underline{i} z \tilde{u} K{ }^{\circ} u$
'He stamped his foot.'
stamp.foot-ABS
'to stamp one's foot'

In fact, showing an $/ \mathrm{m} /$ instead of a $/ \mathrm{p} /$ in the absolute form is a phenomenon not restricted to verbs (and also known from other Tupí languages) (Jensen 1998; Seki 2000). For instance, the nouns $|m \hat{t}|[$ ['mí] 'foot' and /moríwyt| [mo'rtwiẗ] 'custom, culture' both show a stem- initial /p/ in the inflected (possessed) forms, e.g. lit-pt́/ [i'pit] 'my foot' or /ozo-portwyt/ [ozspo'ritwiț] 'our (excl) culture. 25

The following example (20), with a finite and the absolute form of the

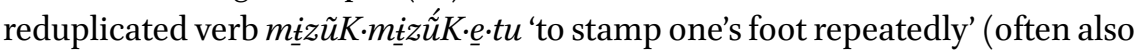
by a group of people, as this activity is part of several rituals), shows that the process of changing the $/ p /$ to $/ \mathrm{m} /$ is not just, say, a phonetic phenomenon which occurs word-initially. It shows also that the initial $/ \mathrm{m} /$ is not a prefix but an integral part of the stem, which happens to have two different allomorphs, one for all inflected forms and one for the absolute form. For building the absolute form of the reduplicated verb, reduplication takes the simple absolute stem allomorph $m \underline{i} z \tilde{u} K$ as its input.
a. $\tilde{m} m \tilde{t} \tilde{t}_{\imath} \tilde{u} \eta \tilde{t}^{\prime} z \tilde{u} \eta \varepsilon$

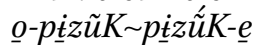 3-stamp.foot stamp.foot-TV 'He stamped his foot repeatedly.' b. $m \tilde{t}, z \tilde{u} \eta m \tilde{t} \tilde{t}^{\prime} z \tilde{u} \eta \varepsilon t u$ $m \underline{i} z \tilde{u} K \sim m \underline{z} z \tilde{u} K-\underline{e}-t u$ stamp.foot $\sim$ stamp.foot-TV-ABS 'to stamp one's foot repeatedly'

The $p / m$ alternation is independent of the orality or nasality of the stem in question. The next example (21) shows $m a ́ P .{ }^{\circ} u$ 'to end, to be over, to be used up,' an intransitive verb with an oral stem, and its reduplicated counterpart maP.máP.e.tu 'to end (of several).'

25 Obviously, $p \dot{t} / m \dot{t}$ 'foot' is also the first element in the lexicalized verb $m \underline{i} z \tilde{u} K \cdot{ }^{\circ} u$ in (19). 

(21) a. s'pap

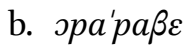
o-páp
$\underline{o}-p a P \sim p a ́ P-\underline{e}$
3-end
3-end $\sim$ end-TV
'It ended, it is used up.' 'Several ended, e.g. a people became extinct.'
c. 'mapu
d. ma'maßetu
$m a ́ P-{ }^{\circ} u$
maP máP-e-tu
end-ABs
end $\sim$ end-TV-ABS
'to end, to be used up'
'to end (plural subject)'

There are several interesting facts to be observed in (21). For one thing, it can again be seen that sequences of (homorganic) consonants at the morpheme boundary are phonetically reduced $(21 b \& d)$. More importantly, in a form like (21d) all vowels are phonetically oral, showing that inherently oral vowels $\mathrm{V}_{2}$ are not nasalized even when in an unstressed position and before a phonetically nasal consonant. This is an important argument for inherently oral vowels. (Apparently obvious alternative analyses would assume only nasal and neutral vowels where the neutral vowels would be phonetically realized as oral "by default.")

Consider next moá ${ }^{\circ} u$ 'to shoot' (e.g. an arrow), an intransitive verb where the stem-final consonant $\mathrm{C}_{3} / T /$ is not homorganic with the initial $p / m$, and its reduplicated counterpart moaT.moáT.e.tu 'to shoot (several)' (e.g. arrows, typically in different directions, firing indiscriminately) in (22).
(22) a. o'pwat
b. spwat'pware
o-poáT
3-shoot
o-poaT poáT-e
'He shot [an arrow].'
3-shoot $\sim$ shoot-TV
'He shot several [arrows].'
c. 'mwatu
moát- $\mathrm{u}$
shoot-ABS
'to shoot (e.g., an arrow)'
d. mwan'mwaretu
moaT moáT-e-tu
shoot shoot-TV-ABS
'to shoot (several arrows, in all directions)'

This is, again, a strong argument in favor of the abstract final segment /T/ as an archiphoneme (unspecified for nasality or orality) as postulated in section $1 . / T$ / is phonetically not deleted in the reduplicated verb, at least not in slow speech (this is also reflected by the orthography: $\langle$ opwatpware $\rangle,\langle$ mwan- 
mwaretu $\rangle$ ). Its phonetic outcome varies—before the nasal consonant $/ \mathrm{m} /$, it is realized as $[n]$, as part of the rules of nasal harmony (the outcome depends not only on the preceding vowel, but also on the following consonants). That means that $[n]$ and $[t]$ are not just in complementary distribution among different morphemes ( $[n]$ after nasal vowels, $[t]$ after oral vowels) but actually vary in different occurrences of the same morpheme. The choice of the oral or nasal (or lenited, cf. (26), below) allophone of the final segments $/ P, T, K /$, is thus a phonetic process which takes the phonological forms (with absolute $/ m /$-initial or general $/ p /$-initial allomorphs) as its input.

This behavior of $/ T /$ is also a good argument that phonetically nasal vowels

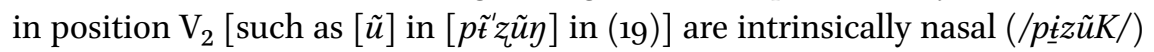
even before morpheme-final nasal segments $[m, n, \eta]$. Alternative analyses could try to avoid abstract archiphonemes $/ P, T, K /$ and propose phonetic nasalization of vowels $V_{2}$ before intrinsically nasal final consonants $C_{3}$, which

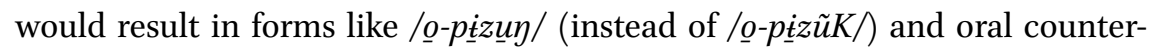
parts /poát/ (instead of /poáT/). But, in such an analysis, even if it could be explained why an intrinsically oral final $/ t$ / would be nasalized in forms like (22d), why does nasality then not also spread to the preceding vowel [not even in $(21 \mathrm{~d})]$ ?

The following examples show the same phenomenon for verbs with a final $/ K /$ and again a final $/ T /$, but in both cases with a thematic vowel - $\underline{e}$ already in the simple verb: móK·ẹ.tu 'to burst' and $m o K \cdot m o ́ K \cdot e \cdot \cdot t u$ '(for several) to burst (and/or at several places), in (23), and móT.e.tu 'to jump' and moT.móT.e.tu 'to bounce, to jump repeatedly,' in (24).

a. э'pэye

o-póK-e

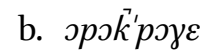

3-burst-TV

o-poK $\sim p o ́ K-\underline{e}$

'It burst.'

3-burst $\sim$ burst-TV

'Many burst,' 'It burst several times, at different places.'

c. 'msyetu

móK-e-tu

d. mog'msyetu

burst-tv-ABS

moK móK-e-tu

'to burst' burst $\sim$ burst-TV-ABS

'(for several) to burst,' 'to burst (in several places)'

(24) a. o'pore

o-pótT-e

b.

3-jump-TV

o-poT póT-e

'He jumped.'

3-jump jump-TV

'He bounced (jumped around).' 


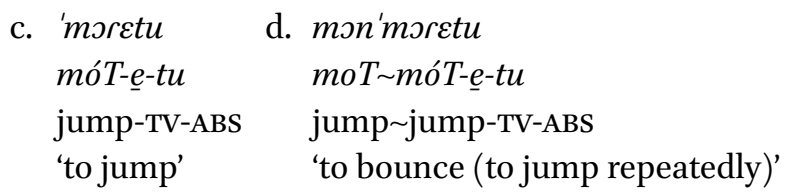

In the preceding three sections 5,6 , and 7 we demonstrated the patterns of reduplication for active verbs, focussing on intransitive active verbs. The next section briefly discusses reduplication with another major class of verbs: stative verbs.

\section{Reduplication with Stative Verbs}

Stative verbs in Awetí (as in other Tupí languages) mainly express concepts which in many other languages are expressed by adjectives. They differ formally from active verbs by several morphological properties, especially with regard to person prefixes (Drude 2008). They also show an obligatory thematic vowel - $\underline{e}$ before the aspectual sufixes. In the absence of aspectual suffixes, the element -(z)ã occurs before most modal suffixes (described as allomorphy of the suffixes in Drude 2011b). Most relevant for this study is the fact that stative verbs also show a different behavior with respect to the thematic vowel - $\underline{e}$ in the case of reduplication. These phenomena will be demonstrated and discussed in this section.

A typical stative verb in Awetí is téP. a.tu 'to be many' (the absolute form is built with the element $-(z) a$. If the suffix $-t u$ occurs after aspect suffixes, $-(z) \tilde{a}$ does not appear). We show the simple third person indicative perfective, imperfective and progressive forms. As can be seen, forms of stative verbs with aspect suffixes show the thematic vowel $-\underline{e}$. The prefix for 3 rd person is $\underline{i}$ - on a consonant-initial stative stem.

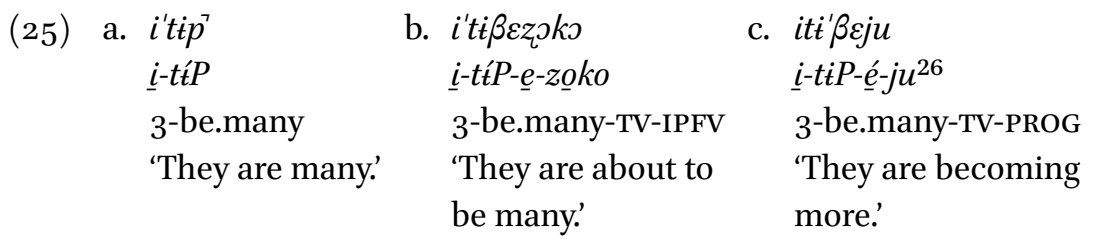

\footnotetext{
26 Interestingly, the word accent in the progressive forms seems to fall on the syllable with the thematic vowel $-\underline{e}$, or at least it varies between this syllable and the (expected) preceding syllable.
} 
Reduplication with stative verbs differs from reduplication with active verbs not only semantically (having an attenuative effect) but also in that the perfective forms (unmarked for aspect) do not receive the thematic vowel -e. Besides this, the reduplicated stems behave just like other stems of stative verbs. We show in (26) a perfective finite form and the absolute form of the reduplicated verb $t i P \cdot t t^{P} P \cdot \tilde{a} \cdot t u$ 'to be relatively (i.e., more or less, not very) many'
a. ${ }^{\prime} t p^{\prime}{ }^{1} t p^{7}$
$\underline{i}-t t^{\prime} P \sim t t^{\prime} P$
b. titp'tîanntu
3-be.many be.many
$t \dot{t} P \sim t_{t} P-\tilde{a}-t u$
'They are relatively many.'
be.many be.many-ż̃-ABS
'to be relatively many'

Also the verb motijj:mottíj.ãatu 'to be a little heavy,' reduplicated from mottíj.ãatu 'to be heavy' ( $p / m$ alternation), does not have the $-e$ characteristic for active reduplicated verbs: the simple perfective 3 rd person forms are $\underline{i}$-pot $\underline{t} \hat{j}$ and $\underline{i}$ potitj pot t́tj, respectively. The same holds for the corresponding forms of tâoóK.ã.tu 'to be angry,' a stative verb with a final $/ K /$, and its reduplicated counterpart ta?oK·ta?óK.ã.tu with, according to some speakers, the (rather active) meaning 'to quarrel (without good reason), to squabble' instead of or in addition to 'to be somewhat angry'.

\section{The Morphological Domain of Reduplication}

So far we have seen reduplication applied only to a morphologically simple ('underlying' or 'proper') stem. No inflectional affixes are included in reduplication in Awetí, not even the thematic vowel $\underline{e}$ or the morph - $z \tilde{a}$, both arguably part of the complete stem of the verb. This poses the question of the morphological domain of reduplication - the behavior of complex (derived and composed) stems with respect to reduplication. Are there any morphs that can be reduplicated together with the stem? And what does this possibly reveal about the nature of these morphs?

The causative prefixes $m \underline{\underline{o}}$ - and $((z) \underline{e}) z(\underline{o})$ - are examples of derivative affixes which are reduplicated together with the original stem. ${ }^{27}$ Both derive transitive from active intransitive verbs. Consider (27) which involves the simple verb kúj.e.tu 'to fall down.'

27 In other words, the complete stem of the derived (transitive) verb is reduplicated, not only the stem of the underlying intransitive verb. 


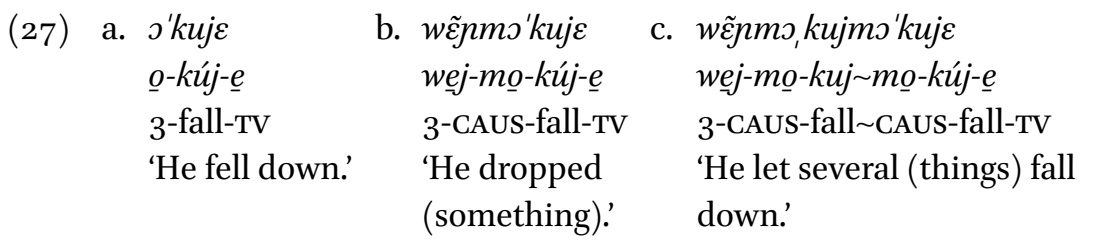

The concomitative-causativizer $((z) \underline{e}) z(\underline{o})$ - is the Awetí affix with the most intriguing allomorphic variation known so far. Its allomorphs vary depending on the segment (consonant or vowel) that follows it and also according to the preceding person prefix (subject-marking or object-marking), as summarized in Table 5, below.

TABLE $5 \quad$ Allomorphs of $((z) \underline{e}) z(\underline{o})$ -

Following segment: Consonant Vowel

Person prefix:

Subject marking

Object marking

$\begin{array}{ll}z \underline{0}- & z \underline{e} z- \\ \underline{e} z \underline{0}- & \underline{e} z-\end{array}$

If the meaning of the original intransitive verb is ' $\mathrm{X}$ does $\mathrm{A}$, then the meaning of the derived transitive verb is ' $\mathrm{X}$ does $\mathrm{A}$ and causes $\mathrm{Y}$ to participate in the same action $\mathrm{A}$ (together with $\mathrm{X})$.'

In reduplication, the prefix $((z) \underline{e}) z(\underline{o})$ - is copied with the root. Interestingly, the right hand copy of the reduplication always contains the allomorph used for object-marking prefixes, even in subject-centred forms. The form of the prefix in the left hand copy depends on the prefix type, as in the simple verb. This is illustrated in (28) for the verb n.ezzo.tó.tu 'to take [(sth.) with oneself], derived from the very common Awetí verb tó.tu 'to go/leave' with the consonant-initial stem tó [cf. (1), above].
(28) a. wejzว ${ }^{\prime} t o$
wej-zo-tó
b. itez̧o'to
3-COCAUS-go
it-ezzo-tó
' $\mathrm{He}_{\mathrm{i}}$ took it with himself $\mathrm{i}_{\mathrm{i}}$
1.OBJ-COCAUS-go
' $\mathrm{He}_{\mathrm{i}}$ took me with himself ${ }_{\mathrm{i}}$ '
c. $w \varepsilon j z \supset, t o \varepsilon z \jmath^{\prime} t o$
wej-zo-to e zzo-tó
3-COCAUS-go COCAUS-go
' $\mathrm{He}_{\mathrm{i}}$ took each of many things with himself ${ }_{\mathrm{i}}$ ' 
It seems odd that the reduplicated form is not just *wej.zo.to.zo.tó, simply copying the prefix allomorph $z \underline{0}$ - as it occurs in the non-reduplicated verb, together with the original stem tó. In terms of a sequence of processes, one might suggest that the allomorph ezo-is the 'default' or 'underlying' one in this case, from which $z \underline{z}$ - is derived by elision of the initial /e/. The choice of the allomorph in the left hand copy is then something which would happen 'later' than reduplication.

The same happens with vowel-initial stems: the right hand copy in the reduplicated form presents the allomorph of the prefix which usually occurs after object-marking prefixes. Compare the examples in (29), completely analogous to the forms in (28), but now with forms of $n \cdot \underline{e} z \cdot u^{\circ} T^{\circ} u^{\prime}$ to bring, derived from the simple verb $t \cdot u ́ t \cdot{ }^{\circ} u[' t u t u]$ 'to come' (stem: úT).

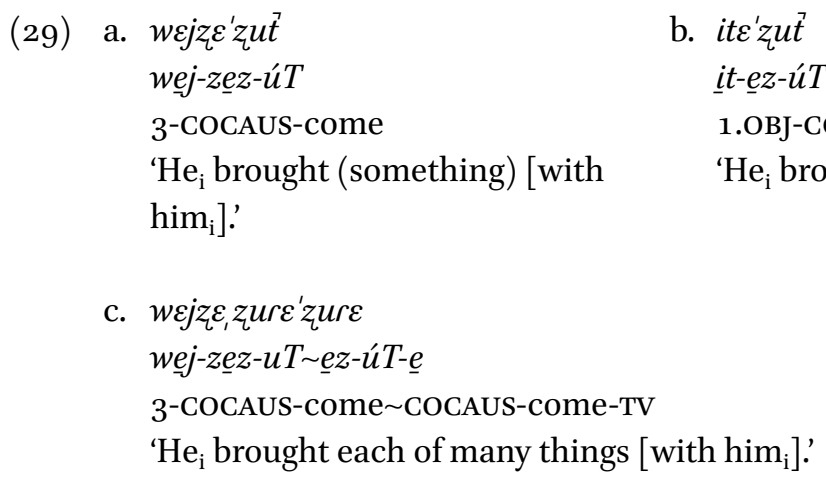

a. $w \varepsilon j z \varepsilon ' z u t$

wej-zez-úT

3-COCAUS-come

'He $\mathrm{H}_{\mathrm{i}}$ brought (something) [with

$\operatorname{him}_{\mathrm{i}}$ ]'

c. $w \varepsilon j z \varepsilon, z u r \varepsilon ' z u r \varepsilon$

wej-zezz-uT $\underline{e} z-u ́ T-\underline{e}$

3-COCAUS-come COCAUS-come-TV

' $\mathrm{He}_{\mathrm{i}}$ brought each of many things [with him $\mathrm{i}_{\mathrm{i}}$.'

In this case, the right hand copy of the prefix is $\underline{e z-}$, an allomorph which is shorter, not longer, than zezz-, the allomorph occurring in the left hand copy (as expected after a subject-marking prefix). So instead of elision of an initial /e/, we would have epenthesis of an initial $/ z /$ due to the preceding person prefix, in the left hand copy, and in the not reduplicated verb.

However these facts might be analyzed (e.g. in terms of underlying forms, reduplication as affixation to the left or right, or in projection terms etc.), it seems clear that reduplication in Awetí is described best in morphological rather than phonological terms. Interestingly, the reduplication process 'has access' to the underlying morphemes so that, in the reduplicated verb, allomorphs may surface which are not present in the simple verb. ${ }^{28}$

28 This fact weakens the argument against the hypothesis (a) (presented earlier in the discussion of example (4)) that the / $t$ / between the subject person prefix and the proper stem of a transitive verb may be part of the stem. The allomorph of the stem without the 
So far, complex verbs formed by derivation reduplicate their whole stem, including a derivational prefix. The same holds for most derivational suffixes. For instance, transitive verbs (with a meaning ' $\mathrm{X}$ does $\mathrm{A}$ to $\mathrm{Y}$ '), may be causativized by a suffix - ${ }^{\circ} \underline{u} k a ́ T$. The derived verb has a meaning ' $\mathrm{Z}$ makes/lets $\mathrm{X}$ do A to Y.' Interestingly, this suffix attracts word accent, which is evidence that it is part of the new stem of the derived bi-transitive verb. Indeed, even this disyllabic suffix is consistently fully reduplicated with the original stem. See the examples in (30).
a. $w \varepsilon j ' t u p^{\top}$
wej-túP
3-see
'He saw [something]'
b. wej, tupu'kat̉
wej-túP- ${ }^{\circ} k k^{\prime} T$
3-see-CAUS
'He made/let [someone] see
[something].'
c. wejtupu,katupu'kare
wej-tuP- $\underline{u} k a T \sim t u ́ P-{ }^{\circ} \underline{u} k a ́ T-e$
3-See-CAUS See-CAUS-TV
'He made/let [someone] see [each of many things].'

This reduplication of original stem plus - $\underline{u} k a ́ T$ is independent of the number of syllables of the root. In the case of $n \tilde{a} \cdot m i i^{2} \tilde{K} \cdot{ }^{\circ} u^{\prime}$ to appear (to someone), a simple verb with a disyllabic stem, the stem of the reduplicated verb with the meaning 'to show each of several things to someone' is mírîK- ${ }^{\circ} \underline{u} k a T \sim m \underline{i} r i \mathrm{~K}-{ }^{\circ} \underline{u} k a$ á $\mathrm{T}-\underline{e}$

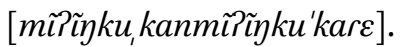

For stative verbs (semantics: 'X has [property] P,' for instance lolé.zã.tu 'to be bad/ugly'), there are two derivational suffixes; both carry the lexical accent of the resulting word. One, the resultative -?áT, derives intransitive active verbs ('X acquires $\left.\mathrm{P}^{\prime}\right)$. This suffix is, again, included in reduplication. As the derived verb lole.?á $T \cdot{ }^{\circ} u$ 'to become bad/ugly' is an active verb, the final thematic vowel -e is present in the reduplicated verb lole.?aT.lole.PáT.ê.tu '(several things/everything) to become bad.'

Finally, the causative suffix -ká derives transitive verbs from stative verbs ('X causes $\mathrm{Y}$ to acquire property $\mathrm{P}$ '). However, unexpectedly, this suffix is not reduplicated with the stem. Compare the examples in (31).

/t/ could be the "underlying" allomorph used for reduplication, and the left hand copy could exhibit the allomorph determined by the environment (following a subject person prefix). 
a. wejlole'ka

wej-lole-ká

3-bad-caus

'He spoiled it.' b. wejlo,lelsle'ka

wej-lole lole-ká

3-bad bad-cAus

'He spoiled several things, each of them.'

However, the semantics of lole.lole.ká.tu 'to spoil (each of) several things' (plural objects) is that of reduplication of the transitive verb lole.ká.tu 'to spoil,' not that of causativation of the reduplicated stative verb lole.lolé.zã $\cdot t u$ 'to be more or less bad/ugly,' which would yield the meaning 'to make something more or less bad.' So, semantics follow the expected pattern observed with the other derivational affixes; but form and semantics go different ways, as illustrated in Table 6.29

TABLE 6 (a) formal and $(b)$ semantic derivations combining -ka and reduplication

(a)

lolé $\quad$ redupl. $\rightarrow$ lole.lole

$\downarrow$ CAUS $\downarrow$

$\downarrow$ CAUS $\downarrow$ (b)

'bad' $\quad$ redupl. $\rightarrow \operatorname{RED}($ 'bad')

$\downarrow$ GAUS $\downarrow$

$\downarrow$ CAUS $\downarrow$

$\operatorname{cAUS}(\operatorname{RED}(\text { bad' }))^{-}$

lole.ká redupl. $\rightarrow$ lole.ka.lole.ká $\quad$ cAus('bad') redupl. $\rightarrow \operatorname{RED(CAUS('bad'))~}$

The odd semantics of lole.lole·ká.tu can be seen as an argument that -ká is a regular derivational affix which happens to show a formal (but not semantic) irregularity not to be copied in reduplication. Indeed, besides this fact there is nothing that would point to another analysis of - ká than that of a derivational affix; it is certainly not an inflectional affix. ${ }^{30}$ The semantic effect is perfectly

29 We restrict the presentation of the formal aspects to the stems, and indicate the semantics in functional notation: $\operatorname{RED}($ 'bad') = 'to be more or less bad'- CAUS $(\operatorname{RED}($ 'bad') ) = 'to make something more or less bad'—CAUs('bad') = 'to spoil'— $-\operatorname{RED}(\operatorname{cAus}($ 'bad') ) = 'to spoil many things.'

30 The only uncommon feature of -ká (and -?áT) is that it does not have a vowel-initial allomorph for use with consonant-final stems (differently from the negation suffix $-k a /-i k a$ ). This suggests rather a lexical origin of -ká (an older verb stem used in compositions?). 


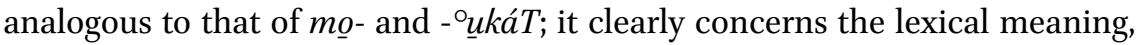

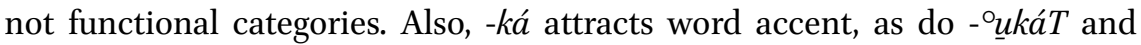
-?áT.

Consequently, reduplication in Awetí formally does not apply to all derivational affixes, but only to most. ${ }^{31}$ I have been unable so far to identify formal or semantic criteria that would determine which affix is reduplicated and which is not. This means, however, that reduplication unfortunately is not a completely reliable formal criterion for distinguishing inflectional from derivational affixes.

As a case in point, consider the two prefixes te- 'reflexive' and to- 'reciprocal,' occurring with transitive stems. They show some properties of derivation. Most importantly, their semantic effect could be described in terms of manipulating the lexical meaning (' $\mathrm{X}$ acts on $\mathrm{X}$ himself' and ' $\mathrm{X}$ acts on $\mathrm{Y}$ and $\mathrm{Y}$ acts on $\left.X^{\prime}\right)$. Then, verb forms with these prefixes take the same person prefixes as intransitive verbs do. These prefixes are illustrated in $(32)$ with the transitive verb $n \tilde{a} \cdot k \hat{x} \hat{y} \cdot t u$ 'to hurt, to combat, to kill.' Note that the original verb shows the transitive third person prefix wej- while the forms with te- and to- contain the third person prefix $\underline{o}$ - which otherwise occurs with active intransitive verbs.

\section{a. $\tilde{w} \tilde{\varepsilon} n^{\prime} k \tilde{t} n$ wej-kítj 3-hurt}

'He hurt someone.'

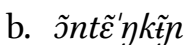
$\underline{o}-\underline{t e}-k \hat{t} \hat{j}$ 3-REFL-hurt 'He hurt himself.' c. $\tilde{\text { ont }} \tilde{n}^{\prime} \eta k \tilde{t} n$ o-to-kítj 3-RECP-hurt 'They hurt one another., 'They fought.'

The behavior of these prefixes could allow for an analysis as derivational prefixes - they would derive active intransitive verbs from transitive verbs. (In particular, the meaning 'to combat' is the most common one with reciprocal forms.)

Nonetheless, the analysis so far (e.g. Drude 2008) considers these prefixes to be inflectional. Accordingly, the forms with these prefixes belong to categories 'reflexive' and 'reciprocal,' and these are names of functional 'voice' (or genus verbi) categories. These forms are part of the paradigm of the transitive verb.

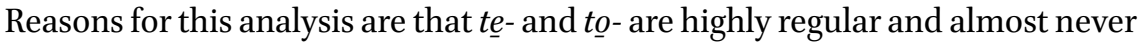
show idiosyncrasies or effects of lexicalization. ${ }^{32}$ The lexical semantic effect is

31 Another derivational suffix which does not (or not always) reduplicate is -wã 'completive,' see (3). Reduplicated verbs with the derivational suffix -túT 'to want to ...' have not been elicited. 
always transparent and concerns only arguments which are already present in the original lexical meaning. It is comparable, for instance, to the semantics of the passive in Germanic languages. Finally, their interaction with the syntactic arguments can explain the change in person prefixes. Like the passive, they reduce the valency.

Interestingly, the forms with te- and to- show variation with respect to reduplication: with some stems the prefixes are reduplicated (present in both copies), but with other stems they are not.

Consider again the reduplicated forms related to the simple verb nãa $\cdot k \hat{t} j \cdot{ }^{\circ} u$ 'to hurt, to combat, to kill.' In this case, the reflexive and the reciprocal prefixes are copied with the original stem $k \hat{t}$ j, as seems to be the case with most if not all monosyllabic stems.
a. $\tilde{n} n t \tilde{\varepsilon}, \eta k \tilde{t} n t \tilde{\varepsilon} \eta \hat{\eta} \tilde{t} \eta \tilde{\varepsilon}$
o-te- $-k \hat{t} j \sim t \underline{e}-k \hat{t} \hat{j}-\underline{e}$
3-REFL-kill RFL-kill-TV
b. $\tilde{n} n t \tilde{\partial}, \eta k \tilde{t} n t \tilde{\jmath} \eta k \tilde{t} \tilde{\varepsilon}$

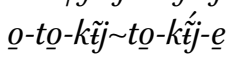
'He hurt himself several times.'
3-RECP-kill RECP-kill-TV
'They fought again and again.'

If the forms with te- and to- are inflected forms of the simple verb, the two forms in (33) are inflectional forms of the reduplicated verb $n \tilde{a} \cdot k \hat{t} j \cdot k \hat{t} j \cdot{ }^{\circ} u$ 'to hurt several times, to combat several times, to kill several beings.' True, this is the only known case where an inflectional affix is reduplicated, and this seems odd at first sight. (The analysis may also have to face certain problems of a semantic nature.)

There are other verbs where the prefixes in question cannot be copied in the left hand copy. For instance, the reflexive form 'he burned himself several times, at several places,' based on the transitive verb nã.?apt.tu 'to

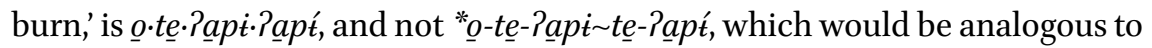
$\underline{o}-t \underline{e}-k \tilde{t} j \sim t \underline{e}-k \hat{t} j$. This variation generally seems to be correlated with the number of syllables, but there are exceptions. The exact conditions for allowing or requiring (or not) reduplication of reflexive/reciprocal prefixes together with the original stem have not yet been identified. They may be partially lexicalized (idiosyncratically), and it seems that there is also some variation from speaker to speaker.

still, also the non-reciprocal forms can mean 'to attack.'- Note that these prefixes are the only known way to express reflexivity/reciprocity in Awetí; there are no independent pronominal reflexive forms or other reflexive morphemes. The same prefixes also occur with prepositions. 
Thus, the fact that forms with te- and to- share properties of both derivation and inflection is mirrored by the variable behavior of these prefixes with respect to reduplication.

A similar situation holds for incorporation. Usually, incorporation derives intransitive verbs from transitive ones by inserting before the verbal stem a noun which refers to the object of the action. This is not a very productive process, often with idiosyncratic (lexicalized) meanings. Only few nominal elements can be incorporated, for instance body parts such as po 'hand,' or mo?áT 'person, human being.' For example, the latter is used to derive the intransitive verb mo?áT.â?ótu 'to swear' from the transitive verb n.ấótu 'to curse.' When reduplicated, the incorporated part is not copied with the root, as is shown in (34).
a. weja'?
b. weja, Pa'? $^{\prime}$

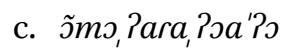
wej-ạó
wej-ạo $\underline{a}$ ?ó
o-mo?aT-ạo a a’ó
3 -curse
3 -curse $\sim$ curse
3-person-curse $\sim$ curse
'He cursed.'
'He cursed a lot, several people.'
'He swore a lot, about/at several people.'

The form * $\underline{0}$-mo?áT- $\underline{a}$ ?o mo?áT-â?ó, which theoretically could exist along with $(34 \mathrm{c})$, is ungrammatical.

On the other hand, there are cases where the incorporated part is reduplicated. For instance, some intransitive verbs are based on the transitive verb $n \tilde{a} \cdot$ Pú $^{\prime} \cdot t u$ 'to ingest (eat, drink, inhale, ...)': kaT.?ú.tu 'to eat, to have a meal' (cf.

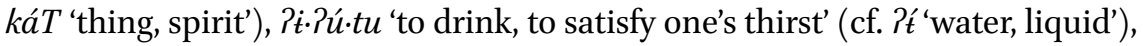
$p e \cdot ? u$ 'tu 'to smoke, to inhale tobacco' (cf. pé 'tobacco'). In contrast to several other verbs with incorporation, with these verbs, the nominal element is reduplicated together with the root. See (35) for forms of nã.?ú.tu and kaT.?ú.tu. The third form of the reduplicated verb kaT.?u-kaT.?útu shows its rather specific inchoative meaning (or, at least, that is the default reading), which suggests lexicalization.
a. $w \varepsilon j ? u$

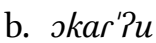
wej-?ú
o-kaT-?ú
c. skar,?ukar'iu
3 -ingest
3-thing-ingest
o-kaT-?u kaT-Pú
'He ate/drunk/
'He had a meal.'
3-thing-ingest $\sim$ thing-ingest
smoked.'
'He started little by little to eat again.'

There are two main possible explanations for this divergent behavior of these verbs: (a) They are rather old (also reconstructed for Tupí-Guaraní, see e.g. 
Mello 200o) and hence possibly lexicalized, so that presently the stem is not analyzed any more, although morphologically transparent. (b) The verbal root ?ú 'ingest' is monosyllabic, and so are the incorporated nouns.

In sum, the morphological domain of reduplication is the stem. In the case of complex stems, generally the whole (derived or composed) stem is reduplicated, but there are exceptions. Some, but not all of these can be explained by lexicalization or number of syllables. On the other hand, the inflectional voice affixes te- and to- are sometimes reduplicated together with the stem, which coincides with the fact that they are in some respects similar to derivational affixes.

\section{Conclusion}

Besides describing the facts of reduplication in Awetí, this study showed that reduplication may provide a useful criterion for answering phonological and morphological questions. The major findings based on reduplication data presented here were the following:

- The analysis of morpheme-final non-glide consonants as abstract archiphonemes due to the neutralization of the oral-nasal contrast has been confirmed (otherwise oral segments may be realized as nasal allophones before nasal consonants).

- The analysis of inherently oral vowels in position $V_{2}$ [see patterns $A$ ] has been strengthened (these vowels are phonetically oral even between nasal consonants).

- The word-initial alternation of $/ p /$ (inflected forms) and $/ \mathrm{m} /$ (absolute forms) is a morphological, not a phonological one (the $/ \mathrm{m} /$ is present in both copies).

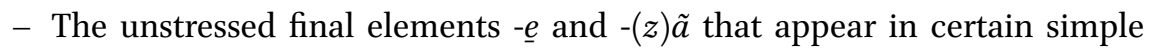
verbs are morphs that do not belong to the proper stem. (They are never reduplicated, and $-\underline{e}$ occurs in many reduplicated verbs.) Interestingly, the same morphs appear in certain inflected forms of stative verbs.

With respect to reduplication itself, the following two facts may be the most interesting:

- In reduplicated verbs, shorter and longer allomorphs that are not present in the simple verb, may occur without a phonological explanation. See examples (28) and (29). 
- When combining derivation and reduplication, form and semantics may diverge with respect to the ordering of applying the respective transformations. See example (31) and Table 6.

\section{Acknowledgments}

The general knowledge of Awetí underlying this study is a result of more than ten years of work on Awetí, including a total of around fourteen months of fieldwork. From 2001 to 2005, the project was supported by the Volkswagen Foundation within the DOBES (Documentation of Endangered Languages) program, focusing on documenting the language and aspects of the culture. From 2008 on, my research has been supported by a Dilthey-fellowship which again allowed me to do fieldwork and to invite speakers to the Museu Goeldi in Belém. Reduplication was studied, and the specific data used in this study was elicited during a field trip in April/May 2009. I am very grateful for the support by the funding agencies, the Museu Goeldi and my Awetí teachers. I also owe thanks to several reviewers of earlier versions of this paper, in particular to an anonymous reviewer and the editors. Remaining shortcomings are mine alone.

\section{References}

Drude, Sebastian. 2002. Fala masculina e feminina em Awetí. In Línguas indígenas brasileiras: Fonologia, gramática e história 1, ed. Ana Suelly Arruda Câmara Cabral and Aryon Dall'Igna Rodrigues, 177-19o. Belém: Ed. UFPA.

2006. On the position of the Awetí language in the Tupí family. In Guaraníy "Maweti-Tupi-Guarani." Estudios históricosy descriptivos sobre una familia lingüística de América del Sur, ed. Wolf Dietrich and Haralambos Symeonidis, 47-68. [Regionalwissenschaft Lateinamerika 11]. Berlin \& Münster: LIT Verlag.

. 2008. Tense, aspect and mood in Awetí verb paradigms: analytic and synthetic forms. In A world of many voices: lessons from endangered languages, ed. David K. Harrison, David Rood and Arienne Dwyer, 67-109. Amsterdam/Philadelphia:John Benjamins.

. 2011a. Nominalization and subordination in Awetí. Amérindia 35 [Special issue La structure des langues amazoniennes II, ed. Francesc Queixalós and Leo Wetzels,] 189-218.

. 2011b. Word accent in Awetí and its manifestation. Amérindia 35 [Special issue La structure des langues amazoniennes II, ed. Francesc Queixalós and Leo Wetzels,] 7-40. 
Halle, Morris. 2008. Reduplication. In Foundational issues in linguistic theory. Essays in honor ofJean-Roger Vergnaud, ed. Robert Freidin, Carlos Peregrín Otero, Maria Luisa Zubizarreta and Jean-Roger Vergnaud, 325-357. [Current Studies in Linguistics 45]. Cambridge, MA: MIT Press.

Jensen, Cheryl Joyce S. 1998. Comparative Tupí-Guaraní morphosyntax. In Handbook of Amazonian languages 4, ed. Desmond C. Derbyshire and Geoffrey K. Pullum, 487-618. Berlin/New York: Mouton de Gruyter.

Meira, Sérgio, and Sebastian Drude. forthcoming. A preliminary reconstruction of Proto-Mawetí-Guaraní segmental phonology. Boletim do Museu Paraense Emílio Goeldi. Ciências Humanas. [Special issue Variação em línguas Tupi: Genealogia, mudança linguística e tipologia, ed. Wolf Dietrich and Sebastian Drude.]

Mello, Augusto A.S. 200o. Estudo histórico da família Tupí-Guaraní: aspectos fonológicos e lexicais. PhD diss., Universidade Federal de Santa Catarina.

Raimy, Eric. 2000. The phonology and morphology of reduplication. [Studies in generative grammar 52]. Berlin/New York: Mouton de Gruyter.

Reiss, Charles, and Marc Simpson. 2009. Reduplication as projection. Concordia University. http://obranch.com/project/redup (accessed September 2010).

Rodrigues, Aryon Dall'Igna. 1953. Morfologia do verbo Tupí. Letras 1: 121-152.

Rodrigues, Aryon Dall'Igna, and Wolf Dietrich. 1997. On the linguistic relationship between Mawé and Tupí-Guaraní. Diachronica XIV/2: 265-304.

Rose, Françoise. 2005. Reduplication in Tupi-Guarani languages: going into opposite directions. In Studies on reduplication, ed. Bernhard Hurch with Veronika Mattes, 351-368. Berlin/New York: Mouton de Gruyter.

-2007. Action répétitive et action répétée: aspect et pluralité verbale dans la réduplication en émérillon. Faits de Langues 29, La reduplication: 125-143.

Seki, Lucy. 200o. Gramática do Kamaiurá, língua Tupi-Guarani do Alto Xingu. Campinas: Editora da Unicamp.

\section{Abbreviations}

$\begin{array}{llll}1 & \text { first person } & \text { IPFV } & \text { imperfective } \\ 3 & \text { third person } & \text { OBJ } & \text { object } \\ \text { ABS } & \text { absolute } & \text { PROG } & \text { progressive } \\ \text { AGNR } & \text { agent nominalizer } & \text { RECP } & \text { reciprocal } \\ \text { CAUS } & \text { causative } & \text { REFL } & \text { reflexive } \\ \text { COCAUS } & \text { concomitative-causative } & \text { RESULT } & \text { resultative } \\ \text { COMPL } & \text { completive } & \text { SUB } & \text { subjunctive } \\ \text { EXCL } & \text { (plural) exclusive } & \text { SUBJ } & \text { subject } \\ \text { INCL } & \text { (plural) inclusive } & \text { TV } & \text { thematic vowel }\end{array}$

